\title{
Goals of Community Colleges in Canada A 1987 Perspective
}

\author{
JOHN D. DENNISON* and JOHN S. LEVIN†
}

\begin{abstract}
Community colleges in Canada are characterized by diversity with respect to their relations with the government, the scope and range of their programs, and the ways in which they respond to societal needs. Nevertheless, the colleges all share a commitment to providing access to a wide range of individuals who need educational opportunities beyond secondary school.

This study examines the goals of community colleges in Canada as perceived by two key groups - chief executive officers, and government personnel in each province who are responsible for college development. The prime purpose was to determine the degree to which these individuals agree on the rating and ranking of their goals and the variations which exist among the provincial systems.

The results indicate that provincial college systems have continued to emphasize the goals which characterized their early development and reflect the differences in priorities which occur by province. While the two groups showed a high level of agreement in each region, a range of priorities existed within each group.

In general, the study provided a restatement of the diversity of ways in which Canada's colleges are attempting to contribute to the economic, sociocultural, and educational development of the nation.
\end{abstract}

\section{RÉSUMÉ}

Ce qui cartactérise le mieux les collèges communautaires, c'est leur diversité, dont les relations avec le gouvernement, la portée et l'étendue des programmes ainsi que la façon dont ils répondent aux besoins de la société sont autant de variables. Cependant les collèges communautaires ont tous en commun l'engagement qu'ils ont pris d'accueillir des personnes très diverses ayant toutes besoin de suivre des cours après l'école secondaire.

Cette étude examine les objectifs des collèges communautaires au Canada tels que les concoivent deux groupes essentiels : les directeurs généraux d'une part, et 
d'autre part, les fonctionnaires chargés du perfectionnement des collèges dans chaque province. Le but premier de cette recherche était de déterminer dans quelle mesure ces deux groupes sont d'accord sur les objectifs à atteindre et sur ceux qui ont un caractère prioritaire, et aussi de montrer s'il y a des différences entre les systèmes des diverses provinces.

Les résultats obtenus indiquent que les collèges communautaires continuent à promouvoir les objectifs qui ont contribué à leur création; ils montrent aussi que l'on accorde la priorité à des objectifs différents selon les provinces. Même si les deux groupes interrogés semblaient tout à fait d'accord dans toutes les régions, on a pu remarquer qu'on accordait un caractère primordial à des objectifs très différents au sein de chaque groupe.

D'une façon générale, cette étude a permis de réaffirmer que c'est par des moyens fort divers que les collèges communautaires du Canada participent au progrès de la nation, tant du point de vue éducatif et écomomique que socioculturel.

\section{Introduction to the Study}

As a partner within the wide spectrum of post-secondary educational institutions in Canada, community colleges have rapidly assumed a broadly accepted role as educational alternatives to both the traditional universities and to the more narrowly focussed technical and vocational institutes. The development of college systems in all regions of Canada is, in itself, a notable phenomenon. In general, this development has occurred over a period of two decades between 1955 and 1975 (Dennison and Gallagher, 1986).

As Gallagher (1987) notes: "Extensive, differentiated, and designed specifically to be responsive to public policy shifts, the community college sector ... has been a catalyst for change and evolution in post-secondary education."

Even within their relatively short period of evolution, Canada's colleges have passed through three distinctive phases of development. The first, roughly between 1955 and 1970, was characterized by autonomy, diversity of curriculum, and virtually unbridled expansion. Government support, particularly in the fiscal arena, was generous. Democratization of opportunity in post-secondary education, accessibility and responsiveness to community needs, and curricular experimentation and comprehensiveness became the themes which characterized the new institutions.

Inevitably, however, financial pressure upon the public treasury generated by the creation of extensive college systems exceeded expectations, and governments soon sought ways to apply their fiscal brakes. Consolidation and constraint became the key phrases as education suspended its priority position within public policy to health, energy needs and social welfare.

Between 1975 and 1980, most provincial college systems experienced increasing control by provincial governments, and with these controls, a 
considerable reduction in new program development, an inability to supply sufficient services to meet the demand, and the imposition of constraints upon student access by restricted admission to particular programs.

The third phase, during the eighties, is characterized by the advent of even greater economic difficulties as Canada entered a period of recession (Macdonald, 1985). Faced with accumulated deficits, partly as a consequence of rapid expansion of services in the public sector during the previous twenty-five years, governments at every level sought ways to reduce spending. Privitization of selected programs, the imposition of specified program priorities upon public institutions, designated funding strategies, and legislation to impose controls upon salary settlements, are all techniques by which governments have exercised fiscal constraints upon the public sector.

In the community colleges, the eighties have become years of retrenchment and restraint. The role of these institutions in contributing to economic growth has been emphasized, while activities aimed at personal and individual development of students have been funded less generously (Dennison, 1986). Colleges have also been encouraged to embark upon various kinds of entrepreneurial activity, designed to garner funds from the private and international community, an exercise which has produced mixed benefits.

Notwithstanding these three phases of college development in Canada, the interesting question remains as to whether the colleges have maintained those goals and functions which generated their establishment in the early years, or whether they have amended their original purposes, adopted new priorities as a result of increasing government intervention into their activities, or simply made minor adjustments to accommodate fluctuations in funding formulae or external demands for services.

Before these questions can be addressed, however, it is important to recognize two characteristics of Canada's community colleges. The first is the relationship which exists between these institutions and their provincial governments. Unlike universities, which have long protected, and been protected by, an assumption that relative autonomy is necessary to ensure high academic quality of teaching and research, the colleges have neither sought, nor been granted, equivalent privileges in this regard.

Provincial college systems in Canada were created by direct and deliberate actions by governments as a matter of public policy during a period of accelerated expansion in educational services. While there are differences in degree among the provinces, colleges remain basically instruments of government policy in matters of tertiary education and job training. It is true that many colleges were created from vocational and technical colleges operated directly by government ministers, and while in most cases governing boards were established to manage the new institutions, considerable duration continued to emanate from the appropriate ministry in the matter of curriculum.

The second important characteristic of Canada's community colleges is also related to the role taken by governments in their establishment. Given the wide 
diversity among Canada's provinces in educational structure, economic needs and priorities, and social and cultural history, it was inevitable that provincial college systems would adopt a variety of organizational models, governance policies, and patterns of curriculum. In this regard, rich diversity has become a feature of Canada's college systems in a manner consistent with the regional diversity which is so characteristic of this nation.

In spite of these diversities, however, it will be argued in this paper that certain common principles may be applied to the community college idea, irrespective of location. In other words, it is possible to identify a number of goals or general functions of colleges which are equally applicable to Newfoundland's institutions as they are to British Columbia's. It is the task of goal identification and description which will be addressed in the following section of this paper.

\section{Community College Goals}

An extensive review of the relevant literature accompanying the creation and evolution of community college systems in all regions of Canada is essential to the identification of those goals and functions which were set for these institutions. These literature sources are many and varied and, in many cases, unpublished. They include government policy statements, planning documents, legislative acts and ministerial announcements - all of which refer to the colleges' role, or proposed role, within the socio-cultural and economic milieu of the particular region.

The second primary sources are the publications by the colleges themselves mission statement, calendars, program outlines, periodic reviews and evaluation studies, and public announcements. Finally, it was necessary to review briefs from a variety of formal and quasi-formal organizations which have a vested interest in college programs and activities. The latter include associations of governing board members, instructor organizations, and various advisory groups.

The task of goal identification was far from easy. Rarely do government documents state, for example, that colleges are designed to respond to economic and political priorities in matters of public policy. However, such goals appear by implication. Mission statements in college calendars are usually idealistic statements of intent, they are less than specific as to what colleges are actually expected to accomplish. Furthermore, it is not at all unusual to find an element of contradiction among the various sources. While high priority may be given to one program area in a college mission statement, government documents in that province may be dramatically silent with respect to such college activity.

\section{The Problem of Diversity}

Reference has already been made to the diverse character of educational structures among the regions of Canada. Provincial college systems reflect this diversity in quite dramatic fashion. However, the literature also reveals another level of diversity which exists among the colleges in any given province. 
For example, largely as a result of their relationship to their communities, there are identifiable differences among the purposes of colleges in rural and urban centres in Saskatchewan, Quebec, or British Columbia. Furthermore, because of the institutional influences which provided the generic roots of colleges in Alberta and Quebec, differing priorities with respect to program development can be identified. In fact, the autonomy granted to Alberta's colleges as a result of their historical funding format has contributed to certain important differences among these separate institutions.

Nevertheless, even with respect and recognition of the problem of diversity, it is possible, as a first step, to delineate a number of common characteristics, or principles, which have contributed to the development of college systems in all provinces and regions of Canada. These common principles may be expressed as follows.

1 The community college is designed to provide access to educational opportunity for societal groups previously denied such access through the imposition of academic, socio-economic, geographic and cultural barriers.

2 The community college will maintain a comprehensive curricular model which provides for both education and training within a broad range of both level and scope of program offerings.

3 Community colleges are designed to emphasize a student orientation through their priority upon quality instruction, faculty-student contact, and accessible and comprehensive counseling services.

4 Community colleges will maintain a community orientation through their governance and program advisory structures.

5 Community colleges will adapt to changes in external phenomena such as new student clienteles, demand for programs of training and education, technological change in program delivery and structure of the workplace.

These five general principles apply to colleges and college systems in all Canadian provinces and regions. Moreover, they are principles which appear to have endured since the establishment of the institutions and remained in force during the three phases of college development noted earlier.

\section{The Goals Inventory}

While recognizing both the problem of diversity and the existence of certain common principles which have guided the development of community colleges in Canada, the next task was to produce a set of statements which reflect the goals of community colleges in each region of the country.

The goal statements which were selected for the final inventory were prepared after an extensive review of the literature, noted earlier, which had been published from the initial period of college development in the late fifties up to and including 1986-87. The range of goal statements does not include, nor was intended to include, reference to all of the general principles outlined previously in this paper. The goal statements are designed to address the three essential roles of the community college as derived from relevant literature: 
... the college as an educational institution.

... the college as a training institution.

... the college as an educational and socio-cultural resource for the community.

The first role focuses upon the students and is designed to produce broad educational competencies such as communication skills, critical thinking, and general knowledge, which are generally to be found in academic program areas. The second role defines the college as a training institution which prepares individuals to enter the workforce with useable job skills.

The third role is one in which the college provides socio-cultural and educational opportunities and environments for a wide range of individuals and groups in the community and, in consequence, becomes a contributor to the overall quality of life in the college region. It must be emphasized that the three roles described above are not independent. Furthermore, a college may well be expected to serve all functions in varying degrees. However, the priority assigned to each role will necessarily influence the kind of institution which emerges.

The goal statements which were finally selected refer to each of the three major roles for the college, but also include additional references to the "political" functions which appear in government documents, ministerial announcements and economic and social planning reports.

The final inventory contained the following statements:

To prepare citizens to cope with problems of society.

To encourage exploration and development of individual potential.

To provide instruction in basic, general education.

To provide broad, comprehensive curriculum for education and training.

To impart knowledge and skills in vocations and in specialized skills.

To train for employment.

To provide access to educational opportunities.

To serve educational interests and needs of community or region.

To serve as a community resource.

To help attain economic priorities of government.

To help attain political priorities of government.

To help attain social priorities of government.

The inventory was first prepared and then shared with a range of individuals who had considerable experience in the college movement and could be classified as experts. Following input from these individuals a number of changes were made, including, for example, the individual categorization of the three priorities of government.

\section{Outline of the Study}

Given that the goals and functions of community colleges in Canada have been the subject of numerous documents, reports, and publications from 1960 until the present time, the purpose of the study was to determine the current status of these goals, the priority assigned to them in the various provinces, and the different values which are placed upon these goals by key constituent groups within the college sector in all provinces. 
The two selected groups which constitute the subjects in the study are the chief executive officers (president, principal, director general) in all of Canada's community colleges, and those officials (senior and middle management) responsible for college development in the appropriate government departments in each province. The ministry personnel were selected to represent those individuals, including the minister and his/her staff, who formulate policy, initiate planning, approve programs, advise, influence and direct college activities and generally ensure the continuation of the college system. They represent, collectively, the government agency responsible for the determination and application of policy. The chief executive officers are primarily responsible for the effective operation of the individual institutions. In collaboration with governing boards, the CEOs determine priorities with respect to their institution's goals and purposes.

These two groups constitute the "key" influences upon the setting of priorities regarding the goals of the provincial system and the individual roles of each of the community colleges. It may be argued that an effective college system would depend in large part upon the extent to which these groups share common understandings as to the purposes of the colleges. Conversely, disharmony could create tensions in the making of decisions such as budgetary allocation and program priorities.

The Goals Inventory (see Appendix) was prepared in both French and English and distributed among the government personnel and the college CEO's in all provinces of Canada. The numbers of respondents varied considerably among the provinces. In some provinces (Ontario, Alberta) the ministries include large numbers of personnel. In other provinces (Prince Edward Island, New Brunswick and Newfoundland) individuals from several ministries are involved in college activities. P.E.I. and Newfoundland have only one college. Table 1 summarizes the distribution and response rates to the Inventory by province.

It should be noted that the individuals were asked to both rate the goals, under one of three categories, and also rank the goals in order of priority.

\section{Results of the Study}

The rankings of the goals by the two respondent groups by province are summarized in Table 2. Based on this table it is apparent that colleges in each province are perceived to respond to a different priority of goals. A summary of the results by province are reported below. Table 3 summarized the rating of the various goals by the provincial respondents.

British Columbia. The primary goal of British Columbia's colleges is consistent with the emphasis placed upon these institutions from the initial period of their development; i.e., to provide increased access to post-secondary education throughout the province. There was some variation between the two respondent groups with respect to curriculum, but general unanimity upon the value placed upon personal development and the response made by colleges to government priorities. The highest rating by CEO's was placed upon accessibility and training 


\begin{tabular}{|c|c|c|c|c|c|c|}
\hline \multirow[t]{2}{*}{ Province } & \multicolumn{3}{|c|}{ Ministry Personnel } & \multicolumn{3}{|c|}{ Chief Executive officer } \\
\hline & $\begin{array}{l}\text { Number } \\
\text { stributed }\end{array}$ & $\begin{array}{c}\text { Number } \\
\text { Returned }\end{array}$ & $\begin{array}{l}\text { Response } \\
\text { Rate }\end{array}$ & $\begin{array}{c}\text { Number } \\
\text { Distributed }\end{array}$ & $\begin{array}{c}\text { Number } \\
\text { Returned }\end{array}$ & $\begin{array}{c}\text { Response } \\
\text { Rate }\end{array}$ \\
\hline British Columbia & 18 & 16 & 89 & 15 & 14 & 93 \\
\hline Alberta & 15 & 12 & 80 & 8 & 8 & 100 \\
\hline Saskatchewan & 10 & 10 & 100 & 15 & 15 & 100 \\
\hline Manitoba & 8 & 8 & 100 & 3 & 3 & 100 \\
\hline Ontario & 36 & 32 & 89 & 22 & 20 & 91 \\
\hline Quebec & 8 & 7 & 87 & 42 & 30 & 72 \\
\hline Prince Edward Is. & 12 & 7 & 58 & 1 & 1 & 100 \\
\hline New Brunswick & 14 & 8 & 57 & 9 & 7 & 78 \\
\hline Newfoundland & 8 & 8 & 100 & 1 & 1 & 100 \\
\hline TOTAL & 129 & 108 & 84 & 116 & 99 & 85 \\
\hline
\end{tabular}

for employment while ministry personnel rated only accessibility (item 3 ) as consistently high in importance.

Alberta. There was broad agreement between the two groups on the ranking of goals. Both accessibility and general preparation for employment were assigned high priority. CEO's displayed greater unanimity on the rating of goals dealing with accessibility and training than did ministry personnel.

Saskatchewan. The role of the colleges in serving as an educational resource was ranked high by all respondents. This particular goal has received major prominence in this province from the inception of the colleges. However, the training function of the colleges was given much higher priority by the CEO's than by the ministry personnel. Both groups placed high priority upon the general education function of the colleges, a phenomenon which was not valued to the same extent in the other three western provinces.

In items of rating of goals, the CEO's place the highest single value upon employment training while the ministry officials regard accessibility as most highly desired. 
Ranking of Goala by Province*

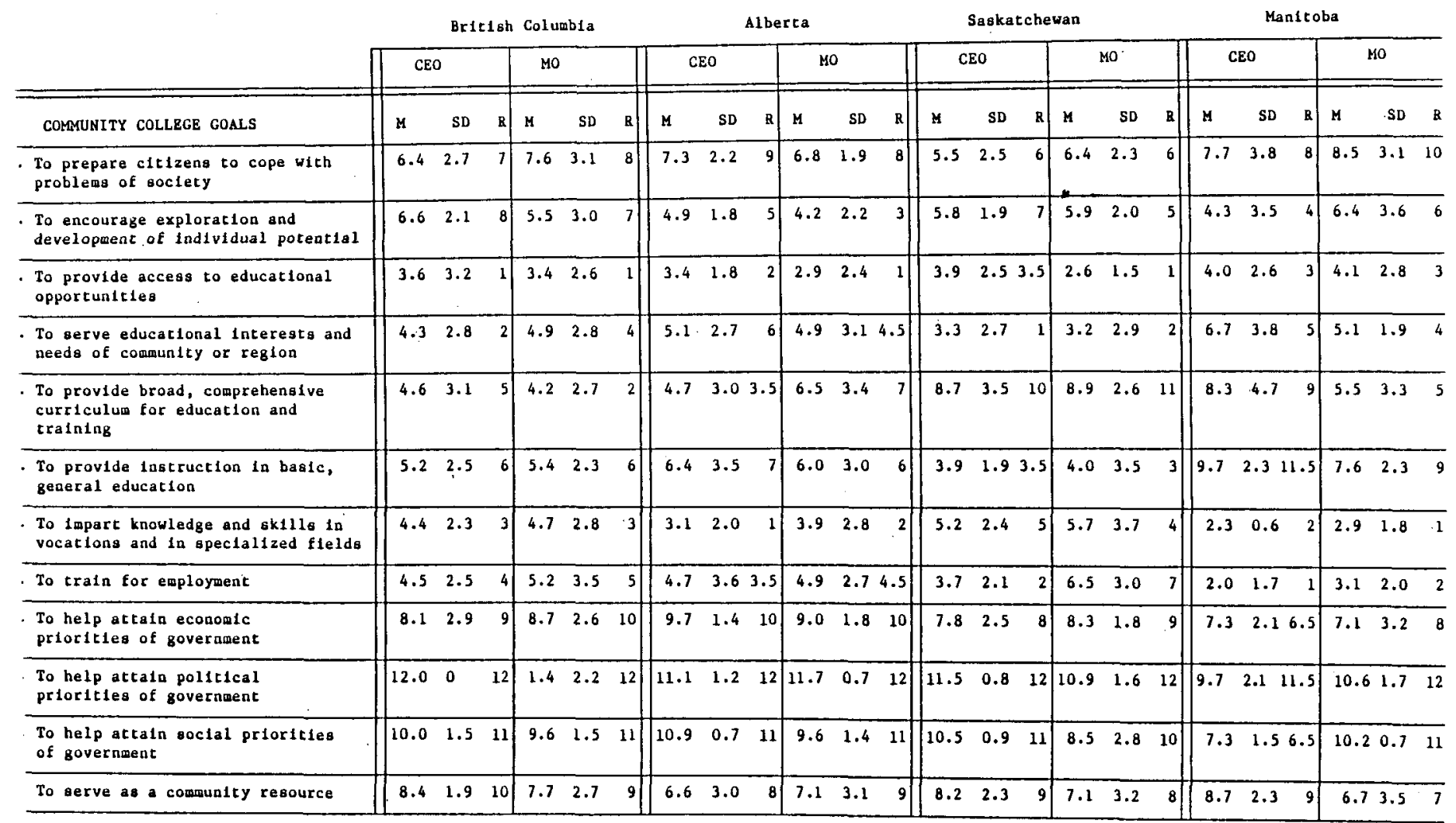


TABLE 3

RATING OF GOALS BY LEVEL OF IMPORTANCE*

\begin{tabular}{|l|l|l|l|l|l|l|}
\hline & \multicolumn{2}{|c|}{ PIGH } & \multicolumn{2}{c|}{ MEDIUM } & \multicolumn{2}{c|}{ LO } \\
\hline & CEO & MO & CEO & MO & CEO \\
\hline BRITISH COLUMBIA & $3,7,8$ & 3 & $1,2,4,5,6,12$ & $2,4,5,6,7,8,12$ & $9,10,11$ & $1,9,10,11$ \\
\hline ALBERTA & $3,7,8$ & 3,7 & $2,4,5,6,12$ & $2,4,5,6,8$ & $1,9,10,11$ & $1,9,10,11,12$ \\
\hline SASKATCHEWAN & 4,8 & 3 & $1,3,6,7$ & $4,6,7,12$ & $2,5,9,10,11,12$ & $1,2,5,8,9,10$ \\
\hline MANITOBA & 7,8 & $3,7,8$ & 2,3 & $1,2,4,5,9,12$ & $\begin{array}{l}1,4,5,6,9,10 \\
11,12\end{array}$ & $6,10,11$ \\
\hline ONTARIO & 7 & 7,8 & $1,2,3,4,5,8,12$ & $2,3,4,5,9,12$ & $6,9,10,11$ & $1,6,10,11$ \\
\hline QUEBEC & 6 & 6 & $1,2,3,4,5,7,8$ & $1,2,3,4$ & $9,10,11,12$ & $5,7,8,9,10,11,12$ \\
\hline NEW BRUNSWICK & $6,7,8$ & 7,8 & $1,3,4,5$ & $3,4,5$ & $2,9,10,11$ & $\begin{array}{l}1,2,6,9,10,11 \\
12\end{array}$ \\
\hline PRINCE EDWARD ISLAND & & $4,7,8$ & & 2,3 & & $\begin{array}{l}1,5,6,9,10,11 \\
12\end{array}$ \\
\hline NEWFOUNDLAND & & $3,4,8$ & & $2,5,6,7,12$ & & $1,9,10,11$ \\
\hline
\end{tabular}

* Numbers refer to the items in the Goals Inventory. 
Manitoba. Training for employment in one form or another is the unanimous priority for the colleges as assessed by the two groups of respondents in Manitoba. General education is given a low ranking by both groups. The rating of goals shows a similarly strong agreement between the two constituent groups with employment related goals being assigned a consistently high value.

Ontario. CEO's and ministry personnel showed little disagreement on the primary goal of the Ontario colleges - preparation for employment! This goal has received prominence from the earliest establishment of the Ontario colleges. However, the CEO's ranked general education goals consistently higher than the ministry personnel. Accessibility goals were unanimously endorsed, albeit at a lower level in the hierarchy.

With respect to the rating of goals, the ministry personnel were almost unanimous on the importance of the training for employment function. CEO's, however, placed greatest value on the more liberal interpretation of training, i.e., "to impart knowledge and skills in vocations and specialized fields".

Quebec. Respondents in the province provided an assessment of goals unlike any other region of Canada. Within both groups "general education" was clearly the primary goal of the colleges. Accessibility ranked a close second, while job training received modest overall support. The CEO's appeared to rank job training somewhat higher than the ministry personnel.

With respect to the value placed upon goals, the pattern was the same. General education was viewed as "very important" by virtually all participants. Conversely, both groups saw little value in colleges as instruments of government policy, with only "social priorities" drawing any notable support.

New Brunswick. New Brunswick's respondents gave unqualified support to colleges as preparation for employment. The ranking of goals by both groups proved to be remarkably consistent, with one exception. Ministry personnel saw colleges as responding to the economic priorities of government; CEO's rejected this function, and substituted one referring to colleges as community resources.

With respect to the rating of goals, there was complete unanimity on the job training aspect of colleges. All respondents rated goals 7 and 8 as "very important".

Prince Edward Island. As there is just one college in this province, it is inappropriate to compare the ranking and rating of goals. However, it is interesting to note that government respondents appeared to see all three major goal areas, access, training, and education, as important in their college. This point of view was also reflected in the rating of goals by the same group. Three of the twelve goals received near unanimous support as "very important".

Newfoundland. Again, there was only one college in this province. However, the ministry personnel and the CEO appeared to hold the same view that the primary function of the college was to meet the educational needs of the community. Both employment training and education were also valued but at a lower level. Goal rating reflected the same priorities. Items 3 and 4 , the accessibility goals, were the only ones to be universally endorsed as being "very important". 


\section{Observations and Conclusions}

As a result of this study there are a number of interesting and pertinent observations which might be made concerning the role and function of community colleges in Canada.

(1) The three major roles of colleges, to expand accessibility to post-secondary education, to train for employment, and to incorporate an educational component into the curriculum, are all valued in every region of the country, albeit at varying levels of importance. These three functions are also traditional, in the sense that college related literature from all sources has, from the nineteen sixties, made reference to such activities as appropriate to the college sector.

(2) In every province respondents valued all goals at varying degrees with the notable and consistent rejection of those referring to colleges as instruments of government policy in social, economic and political areas. In spite of assertions that college-government relations are such that colleges have a direct responsibility within social and economic planning (Skolnik, 1985; Gallagher, 1987), even personnel in ministries of Job Training, Skills Development, and Manpower in various provinces declined to endorse these goals. Whether this function was dismissed on its face value or whether it was the implications which flow from it which were rejected is unclear.

(3) While acknowledging that considerable amount of agreement across Canada exists as to the major goals of colleges, there was also undeniable evidence that different degrees of importance were placed upon these goals in the various regions of the country. This finding is consistent with the acceptance of diversity among college systems (Dennison and Gallagher, 1986).

In the most western provinces, the concept of accessibility in its various forms remains as a continuing role for the colleges. The prime exception is Manitoba whose colleges have experienced a quite different history of development (Department of College and University Affairs, 1978). In Ontario and New Brunswick, the longstanding commitment to broad preparation for employment as the primary college function seems as strong as ever. Quebec has, from the mid-sixties, accepted the college system with respect to its impact upon students (Denis and Lipkin, 1972). In 1987, this commitment remains. In both Prince Edward Island and Newfoundland, where only one such institution is in operation, the notion of diversification of educational opportunities continues to be a primary role of the college. The data provided by this study substantiates the view that colleges in Canada were designed and continue to operate in the context of the socio-cultural, economic and educational differences which exist among the provinces.

(4) The data from the two categories of respondents used in the study, ministry personnel and chief executive officers, invite some interesting observations. In all provinces the ranking of goals was remarkably consistent between the two groups, the correlations ranging between +0.7 and +0.9 . In fact, from a statistical viewpoint, there was greater diversity on goal ranking within the groups than 
between the groups. The very high relationship between goal priorities was somewhat unexpected. It seems that a fair degree of communication regarding college functions and roles exists at provincial levels and, in consequence, a high level of agreement about what colleges are supposed to be doing.

While the foregoing observations can be made, statistical analysis of the data revealed considerable diversity among chief executive officers regarding college goals, presumably based upon their understanding of their own institutions. The diversity was particularly evident between urban and rural colleges, and by the size of the institution. It appears that the current financial climate has caused college presidents to establish priorities in urban areas which are not independent of the presence of other institutions, and to consider economies of scale which are a consequence of size.

\section{Final Comment}

This study has provided a restatement of the mission of community colleges in Canada as post-secondary educational institutions designed to provide increased access for those seeking broadly based preparation to enter the job market or to pursue further education in a variety of fields. While the general functions of colleges in all provinces follow these themes, there is also an element of regional diversity which distinguishes the character of the colleges among various provinces. Nonetheless, the prime differences are based more upon emphasis than upon the nature of the goals.

Given the fiscal pressures under which the institutions have had to operate during the past five years the question remains as to whether they can continue to emphasize their traditional functions under ongoing budgetary restraint and political social change. Based upon this study, it seems that any overt recognition of the colleges' role in meeting specific priorities of government has been resisted.

What is remarkable within this context is the degree to which the colleges, in the view of both government officials and chief executive officers, are pursuing their more broadly based functions. There is no denying the importance of "job training", but even that role is generally perceived in a broader sense of the term.

The study has also invited a variety of further research initiatives. How are the goals of colleges viewed by other important constituent groups; i.e., employers, instructors, students, and the wider community? What will be the impact of the current policy of encouraging industry based, rather than institutionally based programs? What will be the long-term effect of Canadian Job Strategy? Can the goal of broad accessibility be maintained in the face of further financial restraint? Can the comprehensive curriculum survive under more designated funding formulae? Will pressure upon universities force colleges to accommodate more students seeking academic programs?

All of these questions will contribute to increased pressure upon the community colleges in Canada and may redefine their roles. In 1987 it appears that, while a 
range of priorities exist, the colleges are continuing to place high value upon their historical functions. In doing so, these institutions continue to make a particular contribution to the sociocultural, economic and educational wealth of Canada.

\section{REFERENCES}

Denis A. and Lipkin, J. 1972. Quebec CEGEPs: Promise and Reality, McGill Journal of Education, Volume 7.

Dennison, John D. and Gallagher, Paul. 1986. Canadian Community Colleges: A Critical Analysis. Vancouver: University of British Columbia Press.

Department of College and University Affairs. 1978. "A History of Community Colleges in Manitoba". Winnipeg: Colleges Division.

Gallagher, Paul. 1987. Community Colleges in Canada: A Current Profile. Toronto: Association of Canadian Community Colleges.

Macdonald, D. (Chairman). 1985. Royal Commission on the Economic Union and Development Prospects for Canada. Ottawa: Queen's Printer.

Skolnik, M. (Chairman). 1985. Survival or Excellence? A Study of Instructional Assignment in Ontario Colleges of Applied Arts and Technology. Toronto: No Publisher. 


\section{Appendix}

Province:

\section{DEPARTMENT OF ADMINISTRATIVE, ADULT AND HIGHER EDUCATION}

NOTE:

\section{GOALS FOR COMMUNITY COLLEGES}

The following list of goals for community colleges represents a summary of statements extracted from the relevant literature in Canada. (Reports by government, insticutional evaluation teams, college calendars, task force studies, journal articles, etc.) They are presented in no particular order.

You are requested to rate the statements as not important, important, or very important Further, you are requested to rank order the statements ("1" being most important). It is understood that you are judging the goal statements as applicable to community colleges in your province.

\begin{tabular}{|c|c|c|c|c|}
\hline \multirow[b]{2}{*}{ COMMUNITY COLLEGE GOALS } & \multicolumn{3}{|c|}{ RATING (use $X$ ) } & \multirow{2}{*}{$\begin{array}{l}\text { Rank Order } \\
\text { (Top Ten) } \\
\text { (1st, 2nd, } \\
\text { 3rd, etc.) }\end{array}$} \\
\hline & $\begin{array}{c}\text { not } \\
\text { important }\end{array}$ & important & $\begin{array}{c}\text { very } \\
\text { important }\end{array}$ & \\
\hline $\begin{array}{l}\text { 1. To prepare citizens to cope } \\
\text { with problems of society }\end{array}$ & & & & \\
\hline $\begin{array}{l}\text { 2. To encourage exploration and } \\
\text { development of individual potential }\end{array}$ & & & & \\
\hline $\begin{array}{l}\text { 3. To provide access to educational } \\
\text { opportunities }\end{array}$ & & & & \\
\hline $\begin{array}{l}\text { 4. To serve educational interests and } \\
\text { needs of community or region }\end{array}$ & & & & \\
\hline $\begin{array}{l}\text { 5. To provide broad, comprehensive } \\
\text { curriculum for education \& training }\end{array}$ & & & & \\
\hline $\begin{array}{l}\text { 6. To provide instruction in basic, } \\
\text { general education }\end{array}$ & & & & \\
\hline $\begin{array}{l}\text { 7. To impart knowledge and skills in } \\
\text { vocations \& in specialized fields }\end{array}$ & & & & \\
\hline 8. To train for employment & & & & \\
\hline $\begin{array}{l}\text { 9. To help attain economic } \\
\text { priorities of government }\end{array}$ & & & & \\
\hline $\begin{array}{l}\text { 10. To help attain political } \\
\text { priorities of government }\end{array}$ & & & & \\
\hline $\begin{array}{l}\text { 11. To help attain social priorities } \\
\text { of government }\end{array}$ & & & & \\
\hline 12. To serve as a community resource & & & & \\
\hline Thank you for completing this inventory & & & & \\
\hline $\begin{array}{lll}\text { Government } & \square & \text { Board Member } \\
\text { Administration } \square & \text { Instructional Staf }\end{array}$ & CEO & $\square$ Prof & $\begin{array}{l}\text { JOHN. D. } \\
\text { or of Highe }\end{array}$ & $\begin{array}{l}\text { DENNISON } \\
\text { Education. }\end{array}$ \\
\hline
\end{tabular}

